\title{
Introduction to the Biology and Management of Bears
}

\author{
STEPHEN HERRERO \\ Research Associate, Environmental Sciences Centre (Kananaskis) and Assistant \\ Professor, Department of Biology and Psychology, University of Calgary, \\ Alberta.
}

Bears have fascinated man for many thousands of years. Howell (1965) suggested the man-cave bear relationship gave rise to the best known and most durable form of animal worship, the Cult of the Bear, which had its start back in Neanderthal times and persisted until the late Paleolithic-covering a span of some 40, 000 years. Since then men have hunted and shot bears, tamed bears, continued to worship bears, studied bears, and have been intrigued by their behaviour and appearance in zoos, circuses, along roadsides and in their natural environment.

Bears are difficult subjects for scientific study. For most of the year individual bears are either solitary or exist only in small groups, occasionally congregating at choice feeding spots. Most species are wary of man and possess acute senses which enable them to avoid man. Bears are usually challenging animals to observe under natural conditions. Their power, size, relative secretiveness and certain humanoid characteristics (ability to stand on their hind legs, plantigrade feet, involved care of the young) partly account for man's interest in them.

It has become clear during the past two decades that if man is to preserve his wildlife heritage, he must either leave significant areas of appropriate habitat completely alone, something which man has not yet been willing to do, or as an alternative man must, through scientific study, come to understand the life cycles of animal species. This understanding of the requirements of each species can then be used as a basis for regulating the activities of man in areas set aside for wildlife preservation, and also for meeting the basic habitat requirements of each species.

Prior to 1970, little scientific study had been done on bears. Available information came primarily from non-scientific sources:

(1) Reports of early travellers in regions inhabited by bears

(THWAITES, R. G. (ed.) 1904. Original journals of Lewis and Clark expedition, 1804-1806. New York, Dodd, Mead \& Co.,

COUES, E. (ed.) 1965. New light on the early history of the greater northwest. The manuscript journals of Alexander Henry and David Thompson, 1799-1814. Ross \& Haines, Inc., Minneapolis. (Reprint).)

(2) Scholarly literature and historical reviews

(STORER, T. I., \& TEVIS, L. P. 1955. California Grizzly. University of California Press, Berkeley.

COUTURIER, M. A. J. 1954. L'ours brun, Ursus arctos L. Grenoble, Isère, France, Marcel Couturier.) 
(3) The observations of hunters, some of whom performed excellent and detailed natural history studies of bears

(HIBBEN, F.C. 1950. Hunting American bears. J. B. Lippincott Co., Philadelphia \& New York.

MILLS, E. A. 1919. The grizzly: our greatest wild animal. Houghton Mifflin Co., New York.

McCRACKEN, H. 1955. The beast that walks like man. New York, Doubleday \& Co., Inc., 1955.)

(4) Observations on captive bears

(HORNADAY, W. T. 1922. The mind and manners of wild animals. Charles Scribner's Sons, New York.)

(5) Detailed natural history studies

(MURIE, A. 1963. A naturalist in Alaska. Natural History Library edition, Doubleday \& Co., Garden City, New York. (Reprinted).

The natural history technique as developed by an ex-hunter has had its most recent expression in the work of Andy Russell, who has summarized thirty years of association with the grizzly bear (Ursus arctos) in this book Grizzly Country (1967).

Beginning in the late 1950 's and early 1960 's several groups began to apply modern and innovative scientific techniques to the long-term study of bear populations. Most significant among these groups was the Yellowstone National Park study team headed by Drs. John and Frank Craighead. They made the first extensive use of various techniques of capture and marking of individual bears and combined this with the use of radio transmitters which could be attached around the necks of individual bears for long periods of time. These transmitters functioned for years if power sources were renewed. By using these and other research techniques, the Craigheads have been able to determine the movements, reproductive performance, behaviour, habitat preferences and other characteristics of individual animals and of the grizzly bear population in Yellowstone. Most important, through long-term study of this population (the study is now in its twelfth year), the Craigheads are now able to construct life tables through study of the data on fecundity and lifespan gathered from study of individually identified animals. An important supplementary technique here is the ability to determine the age of individual bears through tooth section techniques (Marks and Erickson 1966; Sauer et al.1966).

The Craigheads were the first to institute such comprehensive study of a bear population which for the most part was protected from hunting within a national park. A similar study was begun only a few years later on a hunted population of the big brown bear (U.arctos) on Kodiak Island (Troyer 1961;Berns and Hensel, this volume). Both studies are still in progress, which suggests that a minimum of ten years may be necessary to gain a detailed understanding of the characteristics of bear populations.

Present-day bear management techniques in North America are in most instances based on the results of these and other scientific studies. At the management level, however, conflict has sometimes arisen either over interpretation of study results (see papers by the Craigheads and by Mr. Glen Cole in this volume) or over what goals the parks should have with regard to bear management. Recently, one outspoken biologist has expressed the view that grizzly bears should be eliminated from at least Yellowstone and Glacier 
National parks in the United States because of their potential to injure human beings (Moment 1968, 1970). Many authors have disagreed with Moment's view, showing that he misrepresented the statistical incidence of injury and that his views are impractical and unpopular (Caras 1969; Herrero 1970a). Nonetheless, his views on the extermination of the grizzly may become prevalent unless the public is educated to appreciate this species. Public education concerning bears should be an important function to be carried out by parks personnel, scientists and wildlife appreciators (Herrero 1970b).

The behaviour of individual bears and the social behaviour of groups of two or more bears is another topic to recently come under scientific study. Here, the techniques developed in the field of ethology have been applied and interpreted against supplementary information from ecological, evolutionary and other studies. The preliminary results of some of these studies are reported in this volume. An M.Sc. thesis done by Hornocker (1962) (as part of the Yellowstone project) investigated some aspects of the social behaviour of the grizzly bear. Other relevant studies not stressed in this volume include a review of bear behaviour done by Meyer-Holzapfel (1957), a recent European study on the role of scent-marking in the European brown bear (Tschanz et al.1970) and a study by Masatomi (1964) on the social behaviour of the Yezo Brown bear (U.arctos).

One of the most fascinating characteristics of bears found in the colder parts of temperate regions and in the Arctic is their extended period of winter dormancy or hibernation. Studies have begun to explain the extraordinary physiology of several species of bears during this period. The cubs are born during the dormant phase and several months of nursing and cub care usually take place within the confines of those winter dens which are used for maternity. The female bear during this period neither eats nor drinks and apparently she does not defecate. Scientific study on the physiology of winter dormancy in bears was originally begun by Raymond Hock in the 1950's. For the past several years Dr. G. Edgar Folk, who reports some of his own findings in this volume, has been conducting significant investigations in this area. The actual characteristics of winter dens and factors influencing den site selection have been the subject of detailed investigations which have greatly extended our knowledge of this aspect of the biology of bears (see papers by Lentfer, et al.; Craighead \& Craighead; Uspenski \& Kistchinski, all in this volume; also Harrington 1968).

Certain dimensions of the biology or management of bears were either not discussed or only briefly mentioned at the Second International Conference on Bear Research and Management. Here I would point to economic problems caused by bears, resulting largely from land use competition between bears and the activities of man. Individuals of several species of bears will, under certain circumstances, become predators of livestock or will destroy apiaries (Murie 1948; State of California, 1967; Davenport 1953). Agriculttiral depredation problems may also develop, and on the northern Japanese island of Hokkaido this problem has reached serious proportions (Inukai, this volume). Bears may also be a major threat to silvicultural activities, and managers of second-growth forests have reported extensive problems with bears stripping bark and eating cambium or otherwise damaging trees (Glover 1955; Pierson 1968). These economic encumbrances generated by bears must, however, be carefully assessed against economic (hunting licences and expenses, travel and lodging expenses of persons interested in observing bears, etc.) and aesthetic benefits derived from bears and the natural areas that they occupy.

Another aspect of bear management not discussed at the conference but still important is the zoo raising, care study, and display of bears. Dr. Heinrich 
Dathe of Germany has been a prominent leader in the zoo study and rearing of bears (Dathe 1961, 1963).

Finally, I should point out that the studies reported in this volume on the polar bear (U.maritimus) are only a representative sample of a large quantity of high quality research which is now being conducted on the polar bear. This work is co-ordinated by scientists from five countries which have polar bear populations (Canada, Denmark, Norway, the United States, and the U.S.S.R.). These representatives meet as a working group under the auspices of the International Union for Conservation of Nature and Natural Resources in Morges, Switzerland. Reports from this group constitute an up-to-date summary of major research projects on the polar bear (Survival Service Commission, 1970).

Certain important studies on bears were either not presented at this conference or were not stressed. Realizing that many other important works, especially those done outside of North America may also deserve mention in this context, but may not have been known to this reviewer, I want to draw the reader's attention to the following:

BRAE, O.E., \& BARNES, V.G. 1967. A literature review on black bear populations and activities. National Park Service and Colorado Coop. Wildlife Research Unit, United States.

This is a definitive review of the literature on American black bears up to 1967.

BROMELY, G. 1965. The bears of the southern far east of USSR. Izdatel'stvo 'Nauka' Acad. of Sciences of USSR, Siberian branch, Far east subsidiary, Moscow-Leningrad.

Originally published in Russian but now translated by the Canadian Wildlife Service, Ottawa. This work is a comprehensive, book-length summary of the topic.

ERDBRINK, D. P. 1953. A review of fossil and recent bears of the old world. Orukkerij Jan de Lange, Netherlands. 2 volumes.

A comprehensive but now somewhat out-of-date review of the phylogeny of European and Asian bears.

ERICKSON, A. W., NELLOR, J. \& PETRIDES, G. A. 1964. The black bear in Michigan. Research Bull. 4, Mich. St. Univ. Agric. Expt. Sta., East Lansing Mich.

ERICKSON, A.W. 1965. The black bear in Alaska. Alaska Dept. of Fish and Game, Juneau, Alaska.

These are two of the many publications by the last-mentioned researcher who has been studying bears, especially the black bear, for over a decade.

JONKEL, C. J. 1967. Black bear population studies. State of Montana Job Completion Rept. \# W-98-R-1, 2, 3, 4, 5, 6 Job \# B-1.

Dr. Jonkel, in addition to his polar bear studies reported in this volume, has carried out one of the most thorough population studies of the American black bear.

KROTT, P.\& KROTT, G. 1962. Zum verhalten das braun bären (Ursus arctos L. 1758) in den Alpen. Z.f. Tierpsychol. 20: 160-206.

KROTT, P. 1962. A key to ferocity in bears. Nat. Hist. LXXI: 64-71. 
Dr. Krott studied the behaviour of European brown bear cubs by becoming the 'adopted mother' of two cubs. His study included many days of roaming the Italian Alps with the cubs.

PIERSON, D. J. 1965. Black bear study-population studies. State of Washington, Job Completion Rept., Project No. W 71-R-2.

PIERSON, D. J. \& Hartwell, H. D. 1965. Black bear study-population studies. State of Washington, Job Completion Rept., Project No. W 71-R-3.

Mr. Pierson's research was originally stimulated by black bear damage to second growth forest in the state of Washington. The work was detailed and well co-ordinated and contributed significantly toward understanding the movements, home ranges and food habits of this species.

KURTEN, B. 1968. Pleistocene mammals of Europe Weidenfeld \& Nicolson, London.

Dr. Kurten has been studying the phylogeny of bears and other mammals for many years. The chapter by Herrero in this volume summarizes some of his important work on bears.

RAUSCH, R. L. 1961. Notes on the black bear, Ursus americanus Pallas, in Alaska, with particular reference to dentition and growth. Z.f. Saugetierkunde 26: 65-128.

RAUSCH, R. L. 1963. Geographic variations in size in North American brown bears, Ursus arctos L., as indicated by condylobasal length. Can.J.Zool.41: 33-45.

Dr. Rausch is a leading North American authority on speciation and maturation in black and brown bears. His detailed studies of clinical variations in extensive collections of skulls have clarified and negated earlier claims that as many as 80 species of grizzly bears existed in North America.

THENIUS, E. 1959. Ursidenphylogenese und biostratigraphie. $Z$. Saugertierkunde 24: 78-84.

Dr. Thenius has for many years been conducting detailed investigations into the phylogeny of the European and Asian bears.

Finally, I want to note the obvious North American bias of this introduction and to apologize for any significant research or individuals that I have failed to mention.

The book is dedicated to Dr. Raymond Hock and to Mr. Douglas Pierson, two pioneers in the scientific study of bears, both of whom met unfortunate, accidental death.

\section{REFERENCES}

BERNS, V. D. \& HENSEL, R. J. 1972. In this volume.

BRAE, O. E. \& BARNES, V. G. 1967. A literature review on black bear populations and activities. National park service and Colorado Coop. Wildlife Research Unit. United States.

BROMELY, G. 1965. The bears of the southern far east of USSR. Izdatel'stvo 'Nauka' Acad. of Sciences of USSR, Siberian branch, Far east subsidiary, Moscow-Leningrad. 
CARAS, R. 1969. In defense of the grizzly. Audubon, 71: 53-55.

COUES, E. (ed.) 1965. New light on the early history of the greater northwest. The manuscript journals of Alexander Henry and David Thompson, 17991814. Ross \& Haines, Inc., Minneapolis. (Reprint)

COUTURIER, M. A. J. 1954. L'ours brun, Ursus arctos L. Grenoble, Isére, France, Marcel Couturier.

CRAIGHEAD, F. C. Jr. \& CRAIGHEAD, J. J, 1972. In this volume.

DATHE, von H. 1961. Beobachtungen zur fortpilanzungsbiologie des braunbären, Ursus arctos L. Der Zoologische Garten (NF) 25: 235-249.

DATHE, von H. 1963. Beitrag zur forpflanzungsbiologie des Malaienbären, Helarctos m.malayanus (Raffl.) Z.f.Saugetierkunde 28: 155-162.

DAVENPORT, C.B.Jr. 1953. Agricultural depredation by the black bear in Virginia. J. Wildl. Mgmt. 17: 331-340.

ERDBRINK, D. P. 1953, A review of fossil and recent bears of the old world. Drukkerij Jan de Lange, Netherlands, 2 volumes,

ERICKSON, A. W., NELLOR, J. \& PETRIDES, G. A. 1964. The black bear in Michigan. Research Bull. 4, Mich. St. Univ. Agric. Expt. Sta., East Lansing Mich.

ERICKSON, A.W. 1965. The black bear in Alaska. Alaska Dept. of Fish and Game, Juneau, Alaska.

GLOVER, F.A. 1955. Black bear damage to redwood reproduction. $J$. Wildl. Mgmi. 19: 437-443.

HARRINGTON, C. R. 1968, Denning habits of the polar bear (Ursus maritimus Phipps). Canadian Wildlife Service Report Series-Number 5, Ottawa.

HERRERO, S. 1970a. Human injury inflicted by grizzly bears. Science 170: 593-598.

HERRERO, S. 1970b, Man and the grizzly bear-past, present, but future? BioScience 20: 1148-1153.

HIBBEN, F. C. 1950. Hunting American bears. J. B. Lippincott Co., Philadelphia \& New York.

HORNADAY, W.T. 1922. The mind and manners of wild animals. Charles Scribner's Sons, New York.

HORNOCKER, M.G. 1962. Population characteristics and reproductive behavior of the grizzly bear in Yellowstone National Park. M.Sc, thesis, Montana State University.

HOWELL, F.C. 1965. Early man. Time Inc., New York.

INUKAI, $T$. 1972. In this volume.

JONKEL, C. J. 1967. Black bear population studies. State of Montana Job Completion Rept. \#W-98-R-1, 2, 3, 4, 5, 6 Job \# B-1.

KROTT, P. 1962. A key to ferocity in bears, Nat. Hist. LXXI: 64-71.

KROT'T, P.\& KROT'T, G. 1962. Zum verhalten das braun bären (Ursus arctos L. 1758) in den Alpen. Z.f. Tierpsychol. 20: 160-206.

KURTEN,B. 1968. Pleistocene mammals of Europe. Weidenfeld \& Nicolson, London. 
LENTFER, J. W., HENSEL, R. J., MILLER, L. H., GLENN, L. P. \& BERNS, V. D. 1972. In this volume.

MARKS, S. A. \& ERICKSON, A.W. 1966. Age determination in black bear. J. Wildl. Mgmt. 30(2): 389-410.

MASATOMI, H. 1964. Social relations among young yezo brown bears in captivity. Hokkaido Univ. Ser.6, Zool.15: 401-417.

McCRACKEN, H. 1955. The beast that walks like man. New York, Doubleday \& Co., Inc.

MEYER-HOLZAPFEL, M. 1957. Das verhalten der bären (Ursidae). In Handbuch der Zoologie VIII, part 10(17): 1-28.

MILLS, E.A. 1919. The grizzly: our greatest wild animal. Houghton Mifflin Co., New York.

MOMENT, G.B. 1968. Bears: The need for a new sanity in wildlife conservation. BioScience, 18: 1105-1108.

MOMENT, G.B. 1970. Man-grizzly problems-past and present, implications for endangered species. BioScience 20: 1142-1144.

MURIE, A. J. 1948. Cattle on grizzly bear range. J.Wildl.Mgmt.12: 57-72.

MURIE, A. J. 1963. A naturalist in Alaska. Natural History Library edition, Doubleday \& Co., Garden City New York. (Reprinted).

PIERSON, D. J. 1965. Black bear study-population studies. State of Washington, Job Completion Rept., Project No. W 71-R-2.

PIERSON, D. J. 1968. Black bear study-forest plant relationships. State of Washington, Job Completion Rept., Project No. W 71-R-5, 11pp.

PIERSON, D. J. \& HARTWELL, H. D. 1965. Black bear study-population studies. State of Washington, Job Completion Rept., Project No. W 71-R-3.

RAUSCH, R. L. 1961. Notes on the black bear, Ursus americanus Pallas, in Alaska, with particular reference to dentition and growth. Z.f. Saugetierkunde 26: 65-128.

RAUSCH, R. L. 1963. Geographic variations in size in North American brown bears, Ursus arctos L., as indicated by condylobasal length. Can.J. Zool. 41: 33-45.

RUSSELL, A. 1967. Grizzly country. Knopf, New York.

SAUER, P., FREE, S. \& BROWNE, S. 1966. Age determination in black bears from canine tooth section. N.Y. Fish \& Game J., 13(2): 125-139.

State of California. 1967. Bear management Handbook. State of Calif. Resources agency. Dept. of Fish \& Game. Sacramento, California.

STORER, T. I. \& TEVIS, L. P. 1955. California Grizzly. University of California Press, Berkeley.

Survival Service Commission. 1970. Polar bears. IUCN publications (N.S.), Suppl. paper No. 29, Morges, Switzerland.

THENIUS, E. 1959. Ursidenphylogenese und biostratigraphie. Z. Saugertierkunde 24: 78-84.

THWAITES, R.G. (ed.) 1904. Original journals of Lewis and Clark expedition, 1804-1806. New York, Dodd, Mead \& Co., 
TROYER, W. A. 1961. The brown bear harvest in relation to management on the Kodiak Islands. Trans. 26th. N.Amer. Wildlife \& Nat'l. Resources Conf. $\therefore$ : $460-468$.

TSCHANZ, von B., MEYER-HOLZAPFEL, M. \& BACHMANN, S. 1970. Das informationsystem bei braunbären. Z. Tierpsych. 27: 47-72.

USPENSKI, S. M. \& KISTCHINSKI, A. A. 1972. In this volume. 